\title{
Elites and American power in an era of anti-elitism
}

\author{
Inderjeet Parmar ${ }^{1}$
}

(C) Macmillan Publishers Ltd 2017

The election of Donald Trump to the presidency of the USA - on a platform of opposition to the Washington-based political elite-has shaken the foundations of American power and opened new spaces for the discussion of how power works in the USA. The leadership of both main political parties, the mass media and political commentariat, and academic political scientists, failed to predict the popular legitimacy crisis that propelled Trump to the White House as well as the winning of 13 million votes in the Democratic party primaries for the self-declared socialist Senator Bernie Sanders-whose campaign overtly challenged the authority of Wall Street corporations and the 'billionaire class'. Yet, the anti-establishment character of 2016 American politics reveals the complexities of elitism and anti-elitism, the appearance in new form of a deep crisis of the American political system which threatens to overflow into challenges to the post-1945 international order that it built and presided over. 2016 saw for the first time a major party candidate for the presidency questioning America's long-established system of core alliances underpinning its global hegemony-NATO, the treaties with South Korea and Japan, for example, as well as America's role in the middle east. Most controversially, President Trump, rejecting the advice and guidance of the entire intelligence community, including several of his most senior cabinet-level appointments, has questioned US policy of sanctioning Russia in the aftermath of the latter's intervention in the Ukraine. It would appear that, after an absence of several decades, the study of elite power is back on the political and, hence, academic agenda.

When C. Wright Mills published his ground-breaking book, The Power Elite (1956), he only vaguely glimpsed the kind of mass society, anti-elitist, populism that brought Donald Trump to power. Yet, Mills punctured what he called the Great

Inderjeet Parmar

Inderjeet.parmar.1@ city.ac.uk

1 Department of International Politics, City, University of London, Northampton Square,

London EC1V OHB, UK 
American Celebration of the 1950s-a culture narcissistically self-congratulatory, inward looking, celebrating its democratic credentials while becoming increasingly elite-dominated and dangerously attached to a 'military definition of reality' in an age of nuclear politics. In different tones and almost apologetically, President Dwight Eisenhower, having presided over the building of a garrison state, warned of the dangers to democracy of a 'military-industrial complex' and the dominance of federal research contracts in the post-war university. Over 50 years ago, Martin Luther King's definitive 'I Have a Dream' speech, in conjunction with the Civil Rights Movement, provided critical space for the diversification of America's racialised power structure. Despite the strident critique of the mainstream accomplishments of the civil rights struggle by notables such as Malcolm $\mathrm{X}$ and even King himself (Ledwidge et al. 2013), many Americans assumed that the struggles for socio-political, racial and economic equality were resolved during the 1960s. Yet, the eruptions against war and for political rights of the 1960s were hardly quelled, and massive resistance to change hardly extinguished. Both were incorporated into party politics, the middle levels of power, where they festered for decades, awaiting an opportunity to emerge as challenges to order, a new 'irrationality', 'post-truth politics' (Parmar 2012).

Since then, the USA experienced a major shift of income and wealth away from the bottom $50 \%$ of the population towards its upper echelons-the so-called $1 \%$ or, more accurately, the $0.1 \%$. That recognition of the dangers of elite power is back on the intellectual and political agenda is clear-the financial economic excesses of neoliberalism brought home that message in 2008 (Winters and Page 2009; Piketty 2014); the war on terror re-enlivened interest in elite politics (Rogers 2008); the Iraq war brought into sharp relief the gap between neo-conservative foreign policy elites, and their liberal interventionist allies, and the general publics of many countries (Parmar 2009; Smith 2006); the power of money-and the populist-rhetorical division of American society between the top 1\% and the bottom 99\%-in the 2012 and 2016 US elections showed, once again, the significance of Wall Street in American democracy, as either the supplier of Big Money or the object of political rhetoric, a key factor challenged in the primary campaigns of both Republican Donald Trump and Democratic contender, Bernie Sanders (Center for Responsive Politics 2012), but whose electoral power limits were also exposed by Trump's victory ${ }^{1}$; claims of the re-emergence of the 'military-industrial complex' and, most recently, the 'data surveillance-intelligence complex' as revealed by 'whistleblower' Edward Snowden have resurfaced as huge private corporations continue to win massive arms, security, and other government contracts (Hartung 2012, Luce 2013; Aldrich and Hammond 2014); and the rise of transnational elites continues to make inroads into political democracy in the West and shape international relations across the globe (Sklair 2002; van Apeldoorn and de Graaff 2014). This comes at a time when elites and their decisions are being challenged around the world. Not

\footnotetext{
1 Donald Trump's election success, without significant funding from Wall Street, is remarkable though not as remarkable as the campaign of Sanders whose average donor gave $\$ 27$ to the socialist senator. Both cases suggest that elite power has its limits once popular discontent is galvanised by appropriate leadership.
} 
only is this evident in the favelas of Rio and the squares across the Middle East and North Africa, but also through the consistent leaking of top secret and sensitive information by groups such as WikiLeaks (Parmar 2014), anti-establishment-driven politics of the 2016 US elections, the UK's vote to leave the European Union, and the rising tide of right-wing populist-nationalism across Europe.

While some sociologists have begun re-evaluating the role of elites in society and politics in the twenty-first century (Savage and Williams 2008), mainstream political science and international relations (and the social sciences more generally) remain almost silent on the question of elite power per se-in theoretical terms let alone in terms of political significance in democratic political systems (for a notable exception, Dye 2014). While sociologists have rediscovered elite studies, IR lags behind. Yet, there are clear signs that elite power is being taken more seriously among some IR scholars. This special issue brings together a range of scholars to more systematically examine this issue.

Clearly, matters have moved on in quantum leaps since the 1950s and 1960s: globalisation, cosmopolitanism, neoliberalism, lone superpower status, emerging powers seeking to win a higher status in the global order, greater (though limited) gender and racial diversity across American society's higher echelons, and a hi-tech military that is more lethal in both hardware and software than any seen in world history-and more densely networked and interlocked with other key elite institutions and mindsets than ever before (Giroux 2007).

This special edition of International Politics, one of the most respected leading reviews in the IR and US global power fields, aims to place elite studies back on the IR agenda by providing a forum for serious theoretical, methodological and empirical discussion of American elite power-its raison d'etre, identity profile, institutions, powers and interconnections with academia, think tanks, corporations - national and transnational - and the state. In addition, we aim to extend elite analysis to emerging powers in the global south-to analysing elites in the Middle East and China in the context of US elite power. Hassan considers elite politics and US-Egyptian military complex interconnectedness in the Egyptian 'Arab spring'those heady days that appeared to portend radical change in what were wrongly seen as static social and political systems. DeGraaff and Apeldoorn, with exciting new research on Chinese elite energy corporation directors, US global elite networks, and the differing forms of ties with policy planning and state bodies, argue that Chinese elites remain relatively isolated and viewed as threats to the existing order due to the character of their 'statist' linkages. Layne, in a radical departure, argues that the US foreign policy establishment's attachment to US primacy places SinoUS relations on collision course in the coming decades as China's (understandable) desire for regional hegemony grows. The future direction of such developments is interesting and likely to be significant to both Sino-US relations and world order. The roles of elite institutions and mindsets are fundamental to future outcomes despite the anti-elitist rhetoric of President Trump.

Reflecting on the importance of structural power, we interrogate the relative significance of elite power and structures in the context of the other. Ledwidge and Parmar conceptualise the elitist and racialised (Anglo-Saxonist) character of the US foreign policy establishment, considering it within historical developments and 
situating it in the context of mainstream theories of power and the state that generally ignore or under-emphasise the role of racial identity in the establishment. This inevitably leads to the question of the role of America's first African American president, Barack Obama who, in broad terms, pursued American strategic and foreign policy objectives largely continuous with his Anglo-Saxon predecessors. Parmar and Ledwidge examine the elite processes of socialisation and incorporation, begun in the wake of the civil rights 'revolution' that ultimately brought Obama to the White House. Confirming the findings of Domhoff and Zweigenhaft, in their landmark study, Diversity in the Power Elite (2006), they argue that Anglo-Saxonism is a culturally assimilative force that absorbs elite members of minority communities into dominant mindsets and roles, and maintains existing patterns of power.

Herman Schwartz asks whether a study of elites and elite networks is compatible with structural understandings of power. He argues that the three faces of powerinstrumental, agenda setting and structural-intersect. Elites play key roles and derive greatest benefits from their activities within structural contexts not of their immediate making. Apeldoorn and DeGraaff examine a number of elite think tanks and corporate executives' roles in the construction of Obama's economic recovery strategy in the wake of the global financial meltdown, an attempt to resurrect a global 'open door' to aid US recovery and bolster America's global power. Given global power shifts, however, they are pessimistic about whether American elites can continue to pursue 'business as usual' policies as successfully as in previous eras.

Finally, Kees van der Pijl considers the development of the IR discipline as embodiment of the Wilsonian aim of projecting a Lockean liberal universe of sovereign nation-states 'open for business'. IR essentially serves US power and projects outward its hegemonic impulse in lock-step with the global hegemon, confronting official enemies and promoting regime change.

The workshop from which some of the articles are drawn featured leading scholars including Leslie Sklair (LSE), Kees van der Pijl (Sussex), Thomas Dye (Florida), Bastiaan van Apeldoorn and Nana de Graaff (Free University, Amsterdam), Mark Ledwidge (Canterbury Christ Church), and Inderjeet Parmar (City, University of London), as well as Jeff Henderson (Bristol), among others. The workshop provided the theoretical sophistication, methodological range and empirical research to help launch a new agenda. This special issue, then, aims not only to interrogate the character of elite power in US foreign policy but also to develop an entirely new dynamic and multifaceted research agenda which will place elite studies right back into the centre of political scientific, foreign policy and IR analysis- to show 'how power works' in the modern world.

\section{References}

Aldrich, R.J., and A. Hammond. 2014. Securing freedom: Obama, the NSA, and US Foreign Policy. In Obama and the World, ed. I. Parmar, L.B. Miller, and M. Ledwidge.

Center for Responsive Politics. 2012. http://www.opensecrets.org/news/2012/08/2012-election-will-becostliest-yet.html.

Domhoff, G.William, and R. Zweigenhaft. 2006. Diversity in the power elite. Lanham: Rowman and Littlefield. 
Dye, T.R. 2014. Who's running America? The Obama Reign. Boulder: Paradigm Publishers.

Giroux, H.A. 2007. The chained university: Confronting the military-industrial-academic complex.

Hartung, W. 2012. Prophets of war: Lockheed Martin and the making of the military-industrial complex. Boulder: Paradigm Publishers.

Ledwidge, M., K. Verney, and I. Parmar (eds.). 2013. Barack Obama and the myth of a post-racial America. London: Routledge.

Luce, E. 2013. The Data intelligence complex is the real story. Financial Times, June 7.

Mills, C.W. 1956. The power elite. New York: Oxford University Press.

Parmar, I. 2009. Foreign Policy Fusion: Liberal interventionists, conservative nationalists and neoconservatives - the new alliance dominating the US foreign policy establishment. International Politics 46 (2): 177-209.

Parmar, I. 2012. US Presidential Election 2012: Post-truth politics. Political Insight 3 (2): 4-7.

Parmar, I. 2014. Obama, wikileaks, and american power. In Obama and the world, eds. I. Parmar, L.B. Miller, and M. Ledwidge. London: Routledge.

Piketty, T. 2014. Capital in the twenty-first century. Harvard: Harvard University Press.

Rogers, P. 2008. Global security and the war on terror: elite power and the illusion of control. London: Routledge.

Savage, M., and K. Williams. 2008. Elites: remembered in capitalism and forgotten by social sciences. The Sociological Review 56 (1): 1-24.

Sklair, L. 2002. The transnational capitalist class and global politics: Deconstructing the corporate-state connection. International Political Science Review 23 (2): 159-174.

Smith, T. 2006. A pact with the devil. London: Routledge.

van Apeldoorn, B., and N. de Graaff. 2014. Corporate elite networks and US Post-Cold War grand strategy from Clinton to Obama. European Journal of International Relations 20 (1): 29-55.

Winters, J.A., and B.I. Page. 2009. Oligarchy in the United States? Perspectives on Politics 7 (4): 731-751. 